\title{
DOES THE CURRENT EGYPTIAN AGRICULTURAL EXTENSION SYSTEM NEED REFORM?
}

(Received: 4.11.2015)

\author{
By \\ E. M. I. El-Baaly \\ Department of Agricultural Economics, Faculty of Agriculture, Tanta University, Egypt
}

\begin{abstract}
The purpose of this paper was to assess the degree to which there is a need to restructure the agricultural extension system in Egypt using the FAO framework. A questionnaire containing the 32 items of scheme was prepared and used to collect data from a purposive sample of 68 persons from researchers and agricultural extension workers who attended the tenth national conference of the Egyptian Scientific Society of Agricultural Extension. It could be concluded that the FAO framework is of good utility to assess the state of the agricultural extension system in Egypt. It could also be concluded that the Egyptian Agricultural Extension System is in need of reform in the functional rather than the structural components. This conclusion runs against the series of changes that were centered mainly on the structural component during the last five decades.
\end{abstract}

Key words: Agricultural extension system, Egypt's public agricultural extension system, agricultural extension units, modernizing agricultural extension system.

\section{INTRODUCTION}

The agricultural sector in Egypt employs $29.2 \%$ of the national labor force and generates about $14.5 \%$ of GDP (CAPMAS, 2012). The majority of farmland is individually owned and operated in dwarf holdings mostly less than one feddan (one feddan $=4200 \mathrm{~m}^{2}$ ). Serious national development efforts need to pay attention to the agricultural sector. The Egyptian Agricultural Extension System (EAES) was established in 1953 to assume the responsibility of developing the agricultural sector (Rivera et al., 997). There have been successive efforts to restructure the EAES. Those efforts were imposed by a series of ten decrees said to aim at bringing the EAES closer to achieve its goals (Abd-Ella, 1997). Those decrees were judged to be guided with good will and lack clear professional justification (Al-Gohary, 2011; Al-Gohary et al., 2013; Abd-Ella et al., 2015).

The Food and Agriculture Organization of the United Nations published a scheme to help governments identify whether their agricultural extension systems need to be reformed (Qamar, 2005). In accordance, the Egyptian Scientific Society of Agricultural Extension devoted its tenth national conference to the issue: "Mechanisms of Modernizing of Agricultural Extension in Egypt". Professionals and practitioners were invited to attend and contribute to the conference activities. Sixty eight persons attended the conference. It seemed appropriate to apply the FAO guide on the conference attendants to achieve two complementary objectives. Those were 1) To identify the degree to which the FAO guide is applicable in the case of Egypt; and 2) To identify the degree to which the EAES needs reform.

\section{Materials and methods}

The 68 persons attending the tenth conference of the Egyptian Agricultural Extension Society were considered as a purposive sample of those who care about the EAES. A questionnaire was prepared to be used in data collection. The questionnaire was composed of 32 items. Those items are the Arabic version of the FAO guide with an introductory question asking respondents to read each item and then give their opinion on whether the item applies to the current agricultural extension system in Egypt or not. The questionnaire was handed over to respondents between the conference sessions and retrieved at the end of the conference; percentages of "apply" and "does not apply" responses were computed and presented. 


\section{Results and discussion}

The guide items were grouped under four main subheadings. Those were policy and organizational structure, financing, staffing, and field operation. Results were presented according to those subheadings:

\subsection{Policy and organizational structure}

Framework of Policy and organizational structure contained eleven items (Table, 1). The majority of respondents reported that seven items in this section do not apply in the case of EAES. Those items, in order of percentages, were:

1) Extension staff does not feel constrained by logistic difficulties and a lack of sufficient incentives $(89.7 \%)$.

2) The basis for staff rewards and accountability is objective, based on the performance of each extension worker (72.1\%).

3) The extension services are fully decentralized, with all key decision-making including financial aspects carried out at district or lower level (70.6\%).

4) The country has a national policy on extension (63.2\%).

5) The extension staff at all levels is given frequent opportunities for receiving inservice training to update their technical knowledge and skills (59.4\%).

6) There is an inter-disciplinary committee or unit at the national level, which is responsible for overall coordination, policy advice, and monitoring and evaluation of extension activities $(57.4 \%)$.

7) The extension professional staff enjoys the same level of salaries, benefits, career development, opportunities of in-country and overseas studies and training, adequate operational budget and physical facilities such as proper housing, availability of transport, etc. as enjoyed by the professional staff of other disciplines, notably of

Table (1): Percentages of responses about the framework items of Policy and organizational structure $(\mathrm{N}=68)$.

\begin{tabular}{|l|c|c|}
\hline \multicolumn{1}{|c|}{ Items } & Apply & Not apply \\
\hline $\begin{array}{l}\text { The Ministry of Agriculture runs only main agricultural extension services, and } \\
\text { none of the technical departments within the Ministry has its individual extension } \\
\text { workers in the field. }\end{array}$ & 50 & 50 \\
\hline $\begin{array}{l}\text { There is an inter-disciplinary committee or unit at the national level, which is } \\
\text { responsible for overall coordination, policy advice, and monitoring and evaluation } \\
\text { of extension activities. }\end{array}$ & 42.6 & $\mathbf{5 7 . 4}$ \\
\hline The country does have a national policy on extension. & $\mathbf{3 6 . 8}$ & $\mathbf{6 3 . 2}$ \\
\hline $\begin{array}{l}\text { The extension services are fully decentralized, with all key decision-making } \\
\text { including financial aspects carried out at district or lower level. }\end{array}$ & $\mathbf{2 9 . 4}$ & $\mathbf{7 0 . 6}$ \\
\hline $\begin{array}{l}\text { The government policy encourages non-public institutions, NGOs, the private } \\
\text { sector and farmers' organizations to become involved in the delivery of extension } \\
\text { services, in addition to those delivered by the government department of } \\
\text { extension. }\end{array}$ & $\mathbf{5 5 . 9}$ & $\mathbf{4 4 . 1}$ \\
\hline $\begin{array}{l}\text { The basis for staff rewards and accountability is objective, based on the } \\
\text { performance of each extension worker. }\end{array}$ & $\mathbf{2 7 . 9}$ & \\
\hline $\begin{array}{l}\text { The extension professional staff enjoys the same level of salaries, benefits, career } \\
\text { development, opportunities of in-country and overseas studies and training, } \\
\text { adequate operational budget and physical facilities such as proper housing, } \\
\text { availability of transport, etc. as enjoyed by the professional staff of other } \\
\text { disciplines, notably of researchers. }\end{array}$ & $\mathbf{4 4 . 1}$ & $\mathbf{7 2 . 1}$ \\
\hline $\begin{array}{l}\text { The extension staff at all levels is given frequent opportunities for receiving in- } \\
\text { service training to update their technical knowledge and skills. }\end{array}$ & $\mathbf{4 0 . 6}$ & \\
\hline $\begin{array}{l}\text { Extension staff does not feel constrained by logistic difficulties and a lack of } \\
\text { sufficient incentives. }\end{array}$ & $\mathbf{1 0 . 3}$ & $\mathbf{8 9 . 7}$ \\
\hline $\begin{array}{l}\text { The pre-service academic programmes in agricultural extension that the would-be } \\
\text { extension staff attends at the academic institutions are not just theoretical but of } \\
\text { great practical value, and that is why new extension workers feel very confident } \\
\text { while talking to experienced farmers. }\end{array}$ & 54.4 & 45.6 \\
\hline $\begin{array}{l}\text { Monitoring, evaluation and impact assessment of extension programmesare } \\
\text { carried out on a regular basis. }\end{array}$ & $\mathbf{5 4 . 4}$ & \\
\hline
\end{tabular}


researchers $(55.9 \%)$.

On the other hand, the majority of respondents see that three items apply. Those items in order of percentages were:

1) The government policy encourages nonpublic institutions, NGOs, the private sector and farmers' organizations to become involved in the delivery of extension services, in addition to those delivered by the government department of extension $(55.9 \%)$.

2) The pre-service academic programmers in agricultural extension that the would-be extension staff attends at the academic institutions are not just theoretical but of great practical value, and that is why new extension workers feel very confident while talking to experienced farmers (54.4\%).

3) Monitoring, evaluation and impact assessment of extension programmers are carried out on a regular basis $(54.4 \%)$.

Respondents were equally divided concerning the remaining item: The Ministry of Agriculture runs only main agricultural extension services, and none of the technical departments within the Ministry has its individual extension workers in the field $(50 \%)$.

\subsection{Financing}

The majority of respondents saw that the item about financing which reads " The main funding source for agricultural extension services is not limited to the government and, sometimes, donor-funded projects; there are other sources of funding for extension activities" is not apply (69.1\%) (Table, 2).

\subsection{Staffing}

The majority of respondents saw that all the three items in this sector are apply. Details are shown in Table (2) as follows:

1) About $75 \%$ or more of the total staff, including field extension workers, is based at district, sub-district and lower levels $(66.2 \%)$.

2) The technical subject-matter specialists and field extension workers all combined include at least $20 \%$ female staff $(55.9 \%)$.

3) The technical subject-matter staff is not concentrated (60\% or more) at the central and provincial level (54.4\%).

\subsection{Field Operation}

Framework of Field Operation contained seventeen items (Table, 3).

The majority of respondents saw that ten items are apply (Table, 3).Those items are:

1) The main mandate of extension is not only transfer of improved agricultural technologies to farmers, with some non-extension duties, but also includes non-agricultural educational messages such as environment, population, food security, HIV/AIDS, etc. (80.9\%).

2) Main methods used by the extension services are not limited to traditional method-andresult field demonstrations, farm visits, home visits, individual farmer contact, group farmers contacts, mass media, published materials, but they also use innovative extension modalities $(73.5 \%)$.

3) The extension services make use of modern information technology, as far as possible, in support of extension activities (70.6\%).

Table (2): Percentages of responses about the framework items of Financing and Staffing $(\mathrm{N}=68)$.

\begin{tabular}{|l|c|c|}
\hline \multicolumn{1}{|c|}{ Items } & Apply & Not apply \\
\hline \multicolumn{1}{|c|}{ Financing } & & \\
\hline $\begin{array}{l}\text { The main funding source for agricultural extension services is not limited } \\
\text { to the government and, sometimes, donor-funded projects; there are other } \\
\text { sources of funding for extension activities. }\end{array}$ & 30.9 & 69.1 \\
\hline \multicolumn{1}{|c|}{$\begin{array}{l}\text { The technical subject-matter staff is not concentrated (60\% or more) at } \\
\text { the central and provincial level. }\end{array}$} & 54.4 & 45.6 \\
\hline $\begin{array}{l}\text { About 75\% or more of the total staff, including field extension workers, is } \\
\text { based at district, sub-district and lower levels. }\end{array}$ & 66.2 & 33.8 \\
\hline $\begin{array}{l}\text { The technical subject-matter specialists and field extension workers all } \\
\text { combined include at least } 20 \% \text { female staff. }\end{array}$ & 55.9 & 44.1 \\
\hline
\end{tabular}


Table (3): Percentages of responses about the framework items of Field operations $(\mathrm{N}=68)$.

\begin{tabular}{|c|c|c|}
\hline Items & Apply & $\begin{array}{c}\text { Not } \\
\text { apply }\end{array}$ \\
\hline $\begin{array}{l}\text { The extension staff is mainly accountable to farmers whom they are supposed to } \\
\text { serve, and not just to superior officers within the bureaucracy. }\end{array}$ & 54.4 & 45.6 \\
\hline $\begin{array}{l}\text { The main sources of improved agricultural technologies and recommendations are } \\
\text { not just national agricultural research institutes and research stations; there are } \\
\text { many other technology sources used by the extension workers. }\end{array}$ & 66.2 & 33.8 \\
\hline $\begin{array}{l}\text { Main methods used by the extension services are not limited to traditional method- } \\
\text { and-result field demonstrations, farm visits, home visits, individual farmer } \\
\text { contact, group farmers contacts, mass media, published materials, but they also } \\
\text { use innovative extension modalities. }\end{array}$ & 73.5 & 26.5 \\
\hline $\begin{array}{l}\text { The extension services do not follow any single "imported" extension methodology } \\
\text { only because it was well known or promoted by any major donor through projects } \\
\text { (such as Training \& Visit system or Farmer Field School) or because it was being } \\
\text { practiced in other countries; the extension services use several original extension } \\
\text { methodologies suiting different micro-climate zones of the country, and they have } \\
\text { been developed locally based on the social, economic, geographical and } \\
\text { agricultural conditions of each climatic zone. }\end{array}$ & 61.8 & 38.2 \\
\hline $\begin{array}{l}\text { The extension services have developed and apply modern information technology } \\
\text { tools such as ITC, Internet, etc. }\end{array}$ & 66.2 & 33.8 \\
\hline $\begin{array}{l}\text { The preparation of periodic extension programme plans is not usually done by } \\
\text { extension staff at central or provincial level in spite of the fact that they are the } \\
\text { ones most aware of farmers' needs as well as of the available budget within which } \\
\text { the extension programme is to be prepared. }\end{array}$ & 52.9 & 47.1 \\
\hline $\begin{array}{l}\text { These are farmers' groups at village level whom extension workers involve actively } \\
\text { in preparing plans for agricultural extension services, which are then passed on to } \\
\text { higher authorities for funding and eventual service delivery. }\end{array}$ & 39.7 & 60.3 \\
\hline $\begin{array}{l}\text { Extension workers do not pay most of their attention to male farmers, nor do they } \\
\text { give preference to visiting big farmers, but visit women farmers on an equal basis, } \\
\text { if the country has any. }\end{array}$ & 30.9 & 69.1 \\
\hline $\begin{array}{l}\text { The extension services approach is neither supply-driven nor technology-driven } \\
\text { but is demand-driven and human-focussed. }\end{array}$ & 55.9 & 44.1 \\
\hline $\begin{array}{l}\text { The main mandate of extension is not only transfer of improved agricultural } \\
\text { technologies to farmers, with some non-extension duties, but also includes non- } \\
\text { agricultural educational messages such as environment, population, food security, } \\
\text { HIV/AIDS, etc. }\end{array}$ & 80.9 & 19.1 \\
\hline $\begin{array}{l}\text { Operational funds for field extension activities are always sufficient and extension } \\
\text { staff never complains about shortage of funds. }\end{array}$ & 8.8 & 91.2 \\
\hline $\begin{array}{l}\text { Transport facilities for the field extension staff are adequate to enable the staff to } \\
\text { move from village to village to contact farmers. }\end{array}$ & 20.6 & 79.4 \\
\hline $\begin{array}{l}\text { The number of farmers and the geographical area to be covered by each field } \\
\text { extension worker are not too large for one person, and farmers do not complain } \\
\text { that the extension worker does not visit them often. }\end{array}$ & 19.1 & 80.9 \\
\hline $\begin{array}{l}\text { Operational linkages between extension and agricultural research and other } \\
\text { relevant institutions such as those dealing in farm inputs, credit, marketing, etc. } \\
\text { are indeed strong. }\end{array}$ & 54.4 & 45.6 \\
\hline $\begin{array}{l}\text { The extension staff has a definite say in ensuring timely supply of farm inputs to } \\
\text { farmers, needed for adoption of extension advice based on the recommendations of } \\
\text { researchers. }\end{array}$ & 33.8 & 66.2 \\
\hline $\begin{array}{l}\text { Improved agricultural technologies are always tested by extension workers for } \\
\text { their environment-friendliness before they are recommended to farmers for } \\
\text { possible adoption. }\end{array}$ & 39.7 & 60.3 \\
\hline $\begin{array}{l}\text { The extension services make use of modern information technology, as far as } \\
\text { possible, in support of extension activities . }\end{array}$ & 70.6 & 29.4 \\
\hline
\end{tabular}


4) The main sources of improved agricultural technologies and recommendations are not just national agricultural research institutes and research stations; there are many other technology sources used by the extension workers $(66.2 \%)$.

5) The extension services have developed and apply modern information technology tools such as ITC, Internet, etc.( $66.2 \%)$.

6) The extension services do not follow any single "imported" extension methodology only because it was well known or promoted by any major donor through projects (such as Training\& Visit system or Farmer Field School) or because it was being practiced in other countries; the extension services use several original extension methodologies suiting different micro-climate zones of the country, and they have been developed locally based on the social, economic, geographical and agricultural conditions of each climatic zone $(61.8 \%)$.

7) The extension services approach is neither supply-driven nor technology-driven but is demand-driven and human-focussed (55.9\%).

8) The extension staff is mainly accountable to farmers whom they are supposed to serve, and not just to superior officers within the bureaucracy $(54.4 \%)$.

9) Operational linkages between extension and agricultural research and other relevant institutions such as those dealing in farm inputs, credit, marketing, etc. are indeed strong $(54.4 \%)$.

10) The preparation of periodic extension programme plans is not usually done by extension staff at central or provincial level in spite of the fact that they are the ones most aware of farmers' needs as well as of the available budget within which the extension programme is to be prepared $(52.9 \%)$.

On the other hand, the majority of respondents saw that seven items were "not apply" (Table, 3). Those items were on the order:

1) Operational funds for field extension activities are always sufficient and extension staff never complains about shortage of funds $(91.2 \%)$.

2) The number of farmers and the geographical area to be covered by each field extension worker are not too large for one person, and farmers do not complain that the extension worker does not visit them often (80.9\%).
3) Transport facilities for the field extension staff are adequate to enable the staff to move from village to village to contact farmers (79.4\%).

4) Extension workers do not pay most of their attention to male farmers, nor do they give preference to visiting big farmers, but visit women farmers on an equal basis, if the country has any $(69.1 \%)$.

5) The extension staff has a definite say in ensuring timely supply of farm inputs to farmers, needed for adoption of extension advice based on the recommendations of researchers $(66.2 \%)$.

6) These are farmers' groups at village level whom extension workers involve actively in preparing plans for agricultural extension services, which are then passed on to higher authorities for funding and eventual service delivery $(60.3 \%)$.

7) Improved agricultural technologies are always tested by extension workers for their environment-friendliness before they are recommended to farmers for possible adoption $(60.3 \%)$.

\section{Conclusion and Recommendations}

The findings presented above show that the respondents don't see the EAES to need comprehensive restructuring. However, certain element of the current system need to be reconsidered. First, the policy and organizational structure is not satisfactory. Although extension workers are getting suitable academic training, they are being put into a relatively unsuitable work atmosphere. This is represented by subjective rewarding, imposed centralization and lack of in-service training. Second, while there is an official invitation of the public to help finance agricultural extension activities, there is practically no response. Measure should be taken to encourage the public to provide funding to agricultural extension. This is crucial because there is agreement that current funding is not sufficient. Third, operation at the high levels of the agricultural extension system seem to be in a relatively good shape. But at the local village level (where the actual work is usually done) there are several handicaps including farmer complains, lack of transportation, lack of local tests of new technologies, lack of involvement of women and local groups in extension activities, and uncertainty about securing farm inputs.

\section{Implications}

It became clear that the framework used in this study is of good utility in assessing the state 
of the agricultural extension system in Egypt. When we look at the agricultural extension as a social system having a structural component and a functional component, the findings presented above stress the need for enhancing the functional rather than the structural component. This conclusion runs against the series of changes that were centered mainly about the structural component during the last five decades.

\section{Acknowledgements}

Great thanks are due to Prof. Dr. Mokhtar Abd-Ella, Professor of Rural Sociology and the Ex-chairman of Agricultural Economics Department, Faculty of Agriculture, Tanta University, Egypt for his valuable scientific discussions. He always supports me and assists in cracking difficulties.

\section{REFERENCES}

Abd-Ella M. M. (1997). Basics of Agricultural Extension. Fac. of Agric., Tanta Univ., Tanta, Egypt, p. 170. (Arabic)

Abd-Ella M. M., El-Baaly E. M. and AlGohary A.M. (2015). Agricultural Extension: Science, System and Work, Dargwana for publishing, Elmaady, Cairo, Egypt, p. 367. (Arabic).
Al-Gohary A. M. (2011). The Effect of Agricultural Extension Centers on the Structure and Function of Village-Level Agricultural Extension System in Gharbia Governorate. Ph. D Thesis, Tanta Univ., Egypt. (Arabic).

Al-Gohary A. M., El-Baaly E. M. and Abd-Ella M. M. (2013) Agricultural Extension Centers Enhanced Extension Educational Performance in Egypt. 21 ${ }^{\text {st }}$ European Seminar on Extension Education/ Extension Education Worldwide, Sep. 2- 6, Antalya, Turkey: pp. 305.

Qamar K. (2005). Modernizing National Agricultural Extension System: A Practical Guide for Policy - Makers of Developing Countries, F.A.O.

Rivera W. M., Elshafie E. M. and Abou-Seoud K. H. (1997). The Public Sector Agricultural Extension System in Egypt: A Pluralistic Complex in Transition. J. of Inter. Agric. and Ext. Edu. 4- 67-74.

The Central Agency for Public Mobilisation and Statistics (CAPMAS) (2012). Statistical Yearbook. Available online in: WWW.capmas.gov.eg.

$$
\begin{gathered}
\text { هل يحتاج جهاز الإرشاد الزراعي المصري الحالي إلى إصلاح ؟ عصام محمد إبراهيم البعلي } 1 \text { الاقتصاد الزر اعي- كلية الزر اعة - جامعة طنطا - مصر }
\end{gathered}
$$

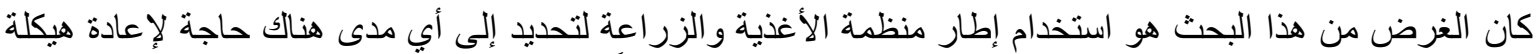

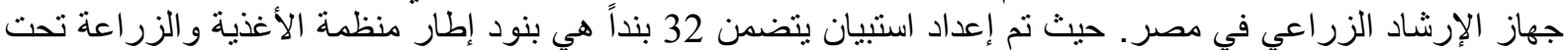
أربعة عناوين فرعية رئيسية هي: السياسة و الهيكل التتظيمي، والتمويل، والتوظيف، والتيف العمل الميداني. وجمعت البيانات

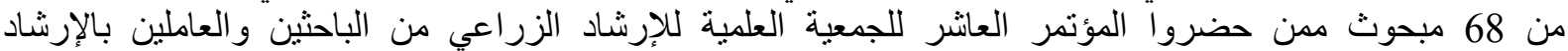

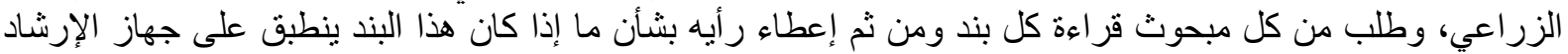

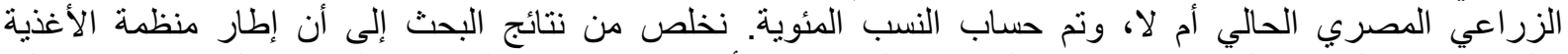

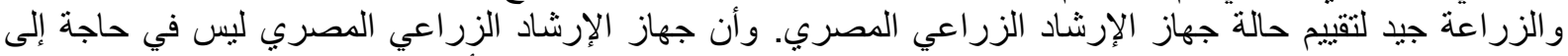

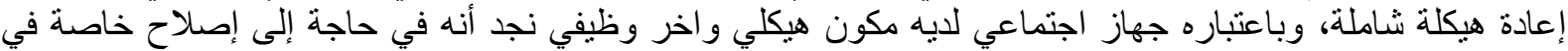

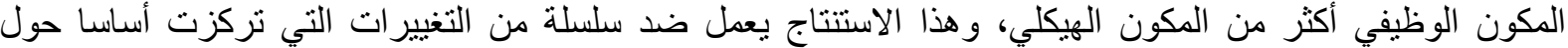
المكون الهيكلي خلال العقود الخمسة المنيفة الماضية. 